\title{
Soil erosion and conservation in two geomorphic and recreational environments
}

\author{
Deirdre Dragovich * \\ University of Sydney, School of Geosciences, Sydney, Australia \\ *Corresponding author e-mail : deirdre.dragovich@sydney.edu.au \\ Received : 19.12.2013 \\ Accepted: 14.04.1014
}

\begin{abstract}
Erosion in recreational areas is often triggered by vegetation removal as a result of activities like walking, horse-riding, camping, motor vehicle use, mountain bike riding, and development of visitor facilities. Sandy soils in two geomorphic settings were investigated for potential differences in erosion patterns and conservation practices. On a coastal sand dune (100\% coarse sand) leading to a popular beach, fencing provided regulated access via rill-eroded, 2 m-wide paths over slopes ranging from 6.5 to 10 degrees and slope lengths from 35 to $45 \mathrm{~m}$. Conservation measures on back-dune paths included repeated spreading of off-site silt/clay-based fill and/or road metal, later replaced by concreting. On the seaward-facing paths where potential erosion rates were estimated to be $>10$ times those on adjacent vegetated areas, a below-surface board-and-chain system was replaced on some paths by low maintenance solid-surface plastic pavers. In a second area, relic cliff-top dunes were traversed by a 26$\mathrm{km}$ walking track with non-vegetated and unfenced pathway segments 1-3 m wide. Soil texture of the cliff-top dune was dominated by coarse sands (coarse:fine:silt of $91: 9:<1$ in the study area) which were eroded by wind, water and mass downslope transfer from walkers' footfalls. Despite gentle slopes $1<5$ degrees), combined erosion processes resulted in hollowing of pathways below adjacent surfaces to depths of up to $40 \mathrm{~cm}$. Where path surfaces became uncomfortable for walkers, or deep gullies developed, visitors widened paths by trampling adjacent vegetation. This study found that costly installations on eroded pathways are feasible for well-frequented, beach-fringing dunes, but not for lengthy walking tracks with long gentle slopes extending for kilometres; and erosion patterns and conservation measures on sandy soils differ in contrasting geomorphic and recreational environments.
\end{abstract}

Keywords: Sands, erosion, recreation pathways, conservation.

\section{INTRODUCTION}

Areas used for recreation often show evidence of increased rates of erosion. In vulnerable situations, frequent and concentrated walking activity along pathways can generate substantial erosion, and introducing horses, mountain bikes and other vehicles to recreation areas generally leads to further soil loss (Wilson and Seney, 1994; Cole and Spildie, 1998; Newsome et al., 2002; Phillips and Newsome, 2002; Dragovich and Bajpai, 2012) along with adverse effects on dune vegetation (De Luca et al., 2011; Ciccarelli, 2014). Development of visitor and camping facilities also depletes vegetation cover and changes surface runoff conditions (Cole, 1986; Monsef and Abahussain, 2013). Generally the most detrimental erosional effects of recreational activities operate through increased runoff following vegetation loss (Morgan and Duzant, 2008), which is exacerbated by soil compaction in finer textured soils and the loosening of surface material in sands. Both surface changes lead to accelerated water erosion and, in the case of sandy soils, additional losses from wind erosion. Pathways traversing local beach dunes and trails in national parks are both used by walkers, resulting in linear erosion patterns which, when soil loss is substantial, impact adversely on vegetation and require conservation measures to be applied in limiting ecological damage and in the interest of public convenience and safety. Patterns of visitor movement may also need to be modified, usually by encouraging or mandating delimited pathways or trails. 


\section{Area Descriptions}

Pathway erosion was examined in two geomorphic settings, one near a popular surfing beach within the Sydney, Australia metropolitan area (Study Area A) and the other in a coastal national park located on the city's southern urban fringe (Study Area B). In Study Area A, a beach dune of (originally) Holocene age is aligned parallel to the beach, separating it from a car park and outdoor showers. The area is managed by the local council and early aerial photographs (1950s) show a major dune blowout which had spread large quantities of sand further inland. The present dune represents the council's reconstruction of the pre-blowout dune into its approximately original position, with current slope angles on both the seaward and landward sides of the dune being constructed rather than naturally-occurring. The dune is composed of coarse sand which is mixed with considerable quantities of broken shell material along its seaward margin. With the exception of grassed areas along the edges of some pathways, organic matter content is low on landward-facing paths and even lower for those on the seaward side. Six paths cross from the landward to seaward sides of the dune, a wider pathway extends along the length of the dune crest to the beach at the northern end, and three additional paths lead from the crest to the beach. These acrossdune paths link the car park and an adjacent recreational park to the beach, and include one path with council vehicle access.

In the early 1980s the council installed fencing along both sides of most paths, thereby enclosing between-path areas for revegetation with native species which included shrubs and grasses capable of withstanding the high saltload environment and the initially bare and unstable sandy surfaces. This vegetation included Spinifex sericeus, Acacia longifolia, Westringia fruticosa, Leptospermum laevigatum and Banksia integrifolia. Successful revegetation stabilised most of the dune apart from its seaward margin. Although only native trees and shrubs were planted, introduced grasses such as kikuyu (Pennisetum secundatum) and buffalo (Stenotaphrum secundatum) were also used along pathways. Colonisation by garden escapes and invaders included bitou bush (Chrysanthemoides monilifera), an introduced weed whose spread has since been partially controlled.

Protection of revegetated sections by fencing resulted in a manipulation of pedestrian activity which was then concentrated on formal pathways, leading to bare areas and their accompanying accelerated rates of erosion. This erosional outcome was exacerbated by pathways being directly aligned over the shortest distance between the car park and beach, resulting in paths traversing the steepest route over the dune. Over time the maintenance of both the pathways and fencing was neglected and paths became uncomfortable for people to walk on, especially as most visitors walk barefoot from the car park to the beach. New informal pathways were formed on the seaward side of the dune by beachgoers who were taking short-cuts to viewing points or avoiding rill-eroded, previously fenced path sections. Such visitor-created paths caused trampling of dune vegetation, creating additional areas of bare sand which over time are likely to be more damaging than managed, formal paths (Wimpey and Marion, 20111.

Intermittent remedial action by authorities was confined to surfaces between fencing. On the backdune face various fill materials, including clayey/silty sediment and road metal, were spread over the paths at different times. This action did not halt rill erosion, and sediment continued to be transferred downslope to the adjacent (asphalted) car park. On the seaward face, initially effective board-and-chain installations became neglected and were either buried under sand near the beach, or exposed boards were undermined by rills and occasionally broken near the dune crest (Table 1). Renewed conservation efforts have since led to reduced erosion on a number of these paths.

Study Area B forms part of a 26-km long coastal hiking track, the Coast Walk, within a national park. The studied section of this unfenced track traverses a cliff-top dune which overlies nearly horizontally bedded Hawkesbury sandstone. Located approximately $1 \mathrm{~km}$ inland from the cliffed shoreline, the site is near a park entrance and is heavily used by visitors preferring to take shorter walks in the park. As these walkers generally follow the same pathway going into the park as leaving it, and it is estimated that the park has up to 4 million visitors annually, footfall traffic is likely to be substantial. The Coast Walk is also used by hikers who generally camp in the park overnight, as well as by guided tours of groups observing nocturnal wildlife. Apart from vehicle access by park authorities for maintenance and emergency purposes (e.g. fire), the Coast Walk is restricted to walkers only. 
Table 1 . Pathway erosion problem, Study Area A (across-dune beach access for surfing, swimming, walking)

\begin{tabular}{|c|c|}
\hline Nature of erosion & Response to erosion \\
\hline Erosion mainly on fenced paths & $\begin{array}{l}\text { Intermittent additions of road metal (gravel) } \\
\text { and clay/silt }\end{array}$ \\
\hline Pathway rill erosion (front and back faces of dune) & Negligible maintenance of fencing \\
\hline Sediment in car park & $\begin{array}{l}\text { Negligible maintenance of board-\&-chain } \\
\text { structures }\end{array}$ \\
\hline Wind erosion $\rightarrow$ sand accumulation, seaward margin & RESULT - \\
\hline Board-\&-chain structures neglected and ineffective & $\begin{array}{l}\text { Further vegetation loss on formal and } \\
\text { informal pathways }\end{array}$ \\
\hline Informal path formation on seaward face & Continuing water and wind erosion \\
\hline
\end{tabular}

The studied pathway section slopes gently, about 5 degrees, with its surface being dominated by coarse sand. Below a depth varying between approximately 20 to $50 \mathrm{~cm}$, sands are underlain by weathering sandstone which also contains some fine sand and minor amounts of silt. In the studied section, deep rills and channels up to $40 \mathrm{~cm}$ deep had formed once this layer had been exposed to water erosion on pathway surfaces, especially along segments where near-surface stone outcrops lead to slightly increased slope angles. At this site movement of sand also occurs as a result of wind erosion, with air flow being concentrated along the pathway by native vegetation of bushes and trees up to a height of $\sim 3 \mathrm{~m}$ on either side. In addition, footfall-generated mass movement contributes to sand redistribution. The pathway here is more than $2 \mathrm{~m}$ wide but is used very infrequently for nonpedestrian purposes.

\section{MATERIAL AND METHODS}

Erosion on pathways was calculated using cross section area (Gager and Conacher, 2001; Olive and Marion, 2009). At Study Site A, cross section area was measured at $5 \mathrm{~m}$ intervals along the length of three landward-seaward paths as well as the northerly, seaward-only, extension of the dune crest path. Additional points were taken at any change in slope. On the dune crest, path measurements were taken at $50 \mathrm{~m}$ intervals with the exception of three sections where path width included extensive grassed areas and cross sectional measurement using a tape was not feasible. At all other points a tape was held taut from one fence post/line to the other, and depth measurements taken at $20 \mathrm{~cm}$ intervals. Slope angle, vegetation cover, surface materials, pathway direction, and surface compaction were also recorded. Eight surface soil samples $(0-10 \mathrm{~cm})$ were collected from positions on the crest, midslope and seaward ends of paths, and analysed for texture (Mastersizer 2000), organic matter (loss on ignition $x$ 1.72), EC (1:5 soil:water suspension) and $\mathrm{pH}$.

At Study Site B, measurements were taken at 10 $m$ intervals along a sandy section of the unfenced Coast Walk. In order to compare erosion at Study Sites $A$ and $B$, maximum soil loss estimates were calculated from path width, path length, and maximum erosion depth. Six surface soil samples (0-10 cm) were collected along the measured path section and analysed for texture, organic matter, $\mathrm{EC}$ and $\mathrm{pH}$ as for Study Site $\mathrm{A}$.

\section{RESULTS AND DISCUSSION}

\section{Surface Materials}

The sands at Study Site A were well-sorted with 100\% coarse sand, and proximity to the ocean and presence of shell material resulted in higher $\mathrm{pH}$ and EC levels here than were recorded at Study Site B. Fine sand and minor amounts of silt comprised about $10 \%$ of surface materials at Study Site B (Table 2). Although samples were taken from bare path areas at Study Site B, the growth of native grasses and understory close to the path, along with the probable addition of fine burnt fragments

Table 2. Surface soil $(0-10 \mathrm{~cm})$ at Study Site A and Study Site B

\begin{tabular}{|c|c|c|c|c|c|c|c|c|}
\hline $\begin{array}{l}\text { Site } \\
\text { location }\end{array}$ & $\begin{array}{l}\text { Samples } \\
\text { analysed }\end{array}$ & $\begin{array}{c}\text { EC } \\
(\mu S / c m)\end{array}$ & $\begin{array}{l}\mathrm{OM} \\
(\%)\end{array}$ & $\mathrm{pH}$ & $\begin{array}{l}\text { Clay } \\
(\%)\end{array}$ & $\begin{array}{l}\text { Silt } \\
(\%)\end{array}$ & $\begin{array}{c}\text { Fine sand } \\
(\%)\end{array}$ & $\begin{array}{c}\text { Coarse sand } \\
(\%)\end{array}$ \\
\hline Study Site A & $n=8$ & 83.7 & 0.8 & 6.7 & 0.0 & 0.0 & 0.0 & 100.0 \\
\hline Study Site B & $n=6$ & 48.3 & 3.3 & 4.1 & 0.0 & 0.6 & 8.6 & 90.9 \\
\hline
\end{tabular}


from earlier bushfires, contributed to organic matter content at this site being higher than at Study Site A. However, organic matter was ineffective in preventing the development of pathway erosion at either site.

\section{Pathway Erosion at Study Site A}

At Study Site $A$, the shortest measured path of $22.5 \mathrm{~m}$ was the concreted vehicle access near the surf life saving club building; the longest pathway was that along the dune crest, over a distance of approximately $560 \mathrm{~m}$. Those paths extending from the car park to the beach were longer on the seaward than the landward side of the dune: 40 $\mathrm{m}$ compared with an average length of $26 \mathrm{~m}$ from the landward face of the dune (Table 3). Except for the concreted vehicle access, the width of pedestrian-created bare ground on pathways did not extend to the fence lines, and did not follow a straight line in places where shrub vegetation, especially A. longifolia, encroached onto a path. A mean bare path width of $1.2 \mathrm{~m}$ was recorded for paths with fenced widths between 1.9 and $2.5 \mathrm{~m}$. These narrower bare areas than were potentially provided by path fencing resulted from pedestrians tending to walk in single file.

Compaction of pathway surface materials was greatest on the pathway where imported soil and minor amounts of gravel had been spread to cover previously eroded bare areas (Table 3). Sandy surfaces recorded expected low to negligible compaction and were measured only to allow for comparisons with those pathways where attempts had been made to smooth over eroded surfaces by spreading soil and/or gravel.

Mean maximum erosion depth $(27 \mathrm{~cm})$ was greatest on the southern end of the dune crest, where sand had been removed from the site, and where the estimated pathway soil loss was also highest $\left(0.1333 \mathrm{~m}^{3} / \mathrm{m}^{2}\right)$ (Table 3). For the two measured paths crossing the dune, estimated soil loss was about $60 \%$ higher on the seaward than the landward face (mean values of 0.0833 compared with $0.0510 \mathrm{~m}^{3} / \mathrm{m}^{2}$ respectively). This reflected the mobility of sandy surface materials in situations where a combination of factors was active: maintenance of board-and-chain conservation

Table 3. Path characteristics and erosion, Study Area A, before installation of pavers

\begin{tabular}{|c|c|c|c|c|c|c|c|c|}
\hline & $\begin{array}{c}\text { Path } 1^{(1)} \\
\text { front }\end{array}$ & $\begin{array}{l}\text { Path } 1^{(1)} \\
\text { back }\end{array}$ & $\begin{array}{l}\text { Path } 4 \text { - } \\
\text { front }\end{array}$ & $\begin{array}{c}\text { Path } 4 \text { - } \\
\text { back }\end{array}$ & Path 7 & $\begin{array}{c}\text { Path } \mathrm{Y} \text { - } \\
\text { front }\end{array}$ & $\begin{array}{c}\text { Path Y - } \\
\text { back }\end{array}$ & Path 8 \\
\hline Use/surface & $\begin{array}{c}\text { Board-\&- } \\
\text { chain, soil, } \\
\text { gravel }\end{array}$ & $\begin{array}{l}\text { Concret } \\
\text { ed }\end{array}$ & $\begin{array}{l}\text { Board-\&- } \\
\text { chain, } \\
\text { soil, } \\
\text { gravel }\end{array}$ & $\begin{array}{l}\text { Soil, } \\
\text { minor } \\
\text { gravel }\end{array}$ & $\begin{array}{l}\text { Beach } \\
\text { sand }\end{array}$ & $\begin{array}{c}\text { Grass, } \\
\text { then } \\
\text { sand; } \\
\text { board-\&- } \\
\text { chain }\end{array}$ & $\begin{array}{c}\text { Soil, } \\
\text { edges } \\
\text { grassed }\end{array}$ & $\begin{array}{c}\text { Bare } \\
\text { sand; } \\
\text { grassed } \\
\text { areas on } \\
\text { soil }\end{array}$ \\
\hline $\begin{array}{l}\text { Path length } \\
\text { (m) }\end{array}$ & 40 & 22.5 & 40 & 28 & 20 & 40 & 28 & $\sim 560$ \\
\hline $\begin{array}{l}\text { Mean slope } \\
\text { angle; range } \\
\text { (degrees) }\end{array}$ & $\begin{array}{c}12 ; \\
3 \text { to } 23\end{array}$ & $\begin{array}{c}14 ; \\
8 \text { to } 17\end{array}$ & $\begin{array}{c}12 ; \\
4 \text { to } 21\end{array}$ & $\begin{array}{c}10 ; \\
2 \text { to } 14\end{array}$ & $\begin{array}{l}4.5 \\
3.5 \text { to } \\
7.5\end{array}$ & $\begin{array}{c}12 ; \\
2 \text { to } 18\end{array}$ & $\begin{array}{c}8 ; \\
2 \text { to } 15\end{array}$ & $\begin{array}{l}2.6 ; \\
1 \text { to } 7\end{array}$ \\
\hline Fenced & 4.1 to & 3 & 2.0 to & 2.1 to & 1.9 to & 2.0 to & 1.8 to & 6; open \\
\hline width (m) & $\begin{array}{c}4.4 \\
(n=10)\end{array}$ & & $\begin{array}{c}2.5 \\
(n=10)\end{array}$ & $\begin{array}{c}2.3 \\
(n=5)\end{array}$ & $\begin{array}{c}2.1 \\
(n=7)\end{array}$ & $2.1(n=8)$ & $\begin{array}{c}2.0 \\
(n=7)\end{array}$ & $\begin{array}{c}\text { space to } \\
21(n=10)\end{array}$ \\
\hline $\begin{array}{l}\text { Mean bare } \\
\text { width; range } \\
\text { (m) }\end{array}$ & $\begin{array}{c}3.3 ; \\
2.3 \text { to } \\
3.8\end{array}$ & n.a. & $\begin{array}{l}1.3 \\
0.7 \text { to } \\
2.0\end{array}$ & $\begin{array}{l}1.9 ; \\
1.7 \text { to } \\
2.1\end{array}$ & $\begin{array}{l}1.6 ; \\
1.2 \text { to } \\
2.1\end{array}$ & $\begin{array}{l}0.8 \\
0.0 \text { to } \\
2.1\end{array}$ & $\begin{array}{c}0.4 ; \\
0.0 \text { to } \\
0.9\end{array}$ & $\begin{array}{l}\text { Range } \\
0.0 \text { to } 5.5 \\
(n=15)\end{array}$ \\
\hline $\begin{array}{l}\text { Mean max. } \\
\text { erosion } \\
\text { depth (cm) }\end{array}$ & 14 & n.a. & 17 & 14 & 6 & 15 & 8 & $\begin{array}{l}N=11 \\
S=27\end{array}$ \\
\hline $\begin{array}{l}\text { Compaction } \\
\left(\mathrm{kgf} / \mathrm{cm}^{2}\right)\end{array}$ & 3.2 & n.a. & 1.51 & 13.6 & 0.0 & 0.5 & 2.5 & $\begin{array}{l}N=0.4 \\
S=0.0\end{array}$ \\
\hline $\begin{array}{l}\text { Estimated } \\
\text { soil loss } \\
\left(\mathrm{m}^{3} / \mathrm{m}^{2}\right)\end{array}$ & 0.0777 & n.a. & 0.0921 & 0.0682 & 0.0281 & 0.0745 & 0.0338 & $\begin{array}{l}N=0.0530 \\
S=0.1333\end{array}$ \\
\hline
\end{tabular}

(1) denotes vehicle access as well as pedestrian use 
measures had been neglected on seaward facing slopes; steeper slope angles occurred on seawardfacing slopes (mean of 12 degrees compared with 9 for back-slopes), along with higher maximum mean slopes of 19 degrees compared with 14.5; in addition to the common components of pedestrian activity, onshore winds and water erosion. The lowest value for soil loss, 0.0281 $\mathrm{m}^{3} / \mathrm{m}^{2}$, was estimated for the sandy, low-angle pathway at the northern end of the dune (Path 7), where any walker-generated sand movement down the gentle slope was countered by onshore winds blowing sand back from the beach. These results from the reconstructed dune at Study Site $A$ contrast with those from levelled dune topography in Israel, where experiments involving trampling and vehicular traffic indicated that herbaceous Mediterranean vegetation was relatively resistant to heavy recreational pressure (Kutiel et al., 2000).

\section{Conservation measures at Study Site A}

Previous erosion-control measures of fencing and board-and-chain had become ineffective to due neglect rather than being inappropriate for the purpose. This resulted in a long period of dune deterioration, associated with soil erosion, vegetation trampling, and weed invasions. Following the acceptance of recommendations in a Plan of Management (Randwick City Council, 1996), the local council began implementing changes in the 2000s. Volunteers completed much of the dune rehabilitation work, including removal of weeds such as bitou bush and replanting of the dune with native vegetation, with funding from the authorities being provided for materials to reestablish fencing (Department of Agriculture and Department of the Environment, 2012). Following these activities, council laid concrete on backdune paths from the car park area, and solid-surface pavers on most pathways facing the sea. The existing board-and-chain installations were left on some of the less-frequented pathways, including on path $Y$, and path 7 has been left in its natural state.

Beachside councils are under pressure to provide recreational facilities for an increasing local population and rising visitor numbers from nonbeachside suburbs. Part of the response has been to 'suburbanise' existing near-natural areas by installing hard-surfaced paths, landscaped car parking, and additional safety measures like sand grooming (removing rubbish/broken glass) and improved official vehicle access to the beach. As sand which is covered by concrete/asphalt/pavers is unavailable for transport by pedestrian activity or erosion, the sand underlying these installations has been stabilized. Also contributing to the substantial reduction in erosion is the attention now being given to maintenance of pathway fencing and the remaining board-and-chain structures. Informal pathways are largely closed off from use and natural revegetation of these areas is taking place.

\section{Pathway Erosion at Study Site B}

The pathway at measured points was wide and sandy, with bare areas effectively representing path width (Table 4). Adjacent vegetation of trees with an understory of shrubs and grasses deterred walkers from wandering off the track unless track conditions became a barrier to easy movement. At the measured points an informal new path had been developed by visitors in order to avoid a nearly 40-cm deep gully within the main path. This resulted in a widening of the area of trampled vegetation and exposure of additional soil surfaces to direct erosive processes, but owing to the newness of the track and the persistence of plant roots, the surface did not display marked hollowing (mean maximum depth of $5 \mathrm{~cm}$ ). Even on the low angle slopes in this section of the Coast Walk, loose surface sand was shifted downslope by footfalls of pedestrians moving along the path in both directions - pushing sand downslope when walking in that direction, and adding to this sand transfer when gaining traction on upslope inclines in the reverse direction. Such walker-generated mass movement created an uneven path surface and led to sand accumulation in any slightly lower topographic positions.

On such a lengthy pathway, the arbitrary 10-m segments measured could be compared with the beach dunes at Study Site A but not with other sections of the 26-km Coast Walk, which has varying geomorphic environments including sections of sandstone outcrops, swampy ground, sandy beaches, and shale-derived clayey soils further south. Slope angles and vegetation assemblages also differ between the varying lithological and drainage conditions along the trail. The pathway section now avoided by walkers in Study Site B recorded the highest estimated maximum soil loss of all measured sections at both study sites. Erosion at the other two sections in Study Site B was estimated to be less than that on the seaward dune face at Study Site A. 
Table 4. Maximum estimated erosion of 10-m path segments, Study Site B

\begin{tabular}{lllll}
\hline Description & $\begin{array}{l}\text { Slope } \\
\text { (degrees) }\end{array}$ & $\begin{array}{l}\text { Mean width of } \\
\text { bare ground; } \\
\text { range }(\mathrm{cm})\end{array}$ & $\begin{array}{l}\text { Mean max. } \\
\text { erosion } \\
\text { depth }(\mathrm{cm})\end{array}$ & $\begin{array}{l}\text { Estimated } \\
\text { maximum } \\
\text { soil loss } \\
\left(\mathrm{m}^{3} / \mathrm{m}^{2}\right)\end{array}$ \\
\hline Segment 1 - Original track (includes gully) & 4 & $151 ; 86$ to 215 & 37 & 0.1794 \\
Segment 2 - Informal new track & 4 & $115 ; 110$ to 121 & 5 & 0.0047 \\
Segment 3 - Main track (part) & 0.5 & $510 ; 470$ to 550 & 11 & 0.0578 \\
\hline
\end{tabular}

\section{Conservation measures at Study Site B}

The pathway segment at this site illustrates some of the difficulties of maintaining long distances of hiking and general recreational tracks in national parks. In other parts of the park, conservation measures include boardwalks, log steps, and guidance markers over rock surfaces, but installation of kilometres of concreted or hardsurfaced path would not be feasible for financial and visitor-satisfaction reasons. Although lowercost plastic materials have been suggested (Capararo and Mitchell, 1995), they have not been installed. Water erosion remains a problem throughout the park, as occasional heavy summer thunderstorms produce runoff which is automatically channelled along pathways. When heavy rains follow bushfires (Zierholz et al., 1995), this effect is magnified due to high runoff rates in the absence of vegetation cover. Sections of paths are closed for rehabilitation if erosion becomes too severe; these paths may be subsequently reopened for public access or long-term alternative routes provided.

Informal pathways widen existing paths, cause loss of vegetation, and increase erosion. As informal paths are an opportunistic response to avoiding difficult pathway surfaces or creating short-cuts to desirable viewing points or intended destinations, they rarely have optimal locations for minimizing erosion. They are thus generally unplanned at a managerial level and not maintained as part of a pathway system (Randall and Newsome, 2008). As a result, environmental degradation is often accelerated at such sites (Randall and Newsome, 2009).

People using the Coast Walk are generally aware of erosion and nearly half of 100 visitors surveyed indicated that they have trampled vegetation in order to avoid unsafe or difficult sections of path (Dragovich and Bajpai, 2012). An overwhelming majority came to the park to enjoy the beauty of nature and, in order to meet their expectations, minimal interference with the natural environment is desirable. This contrasts with the situation for the beachside dune at Study Site A, where the main purpose of visitors is not to view the dunes, but to traverse them in order to undertake beach-based leisure activities like surfing, swimming, or walking. The hard surfaces of car parks and pathways provide convenience in achieving this, although care needs to be taken that rills do not develop along the sides of concreted paths as has occurred in the past.

\section{CONCLUSION}

Study Site $A$ is a coastal sand dune representing a suburban leisure destination where the 'nature' that people wish to enjoy is represented by the ocean and the beach, not the dune and its vegetation. Visitor satisfaction is therefore directed towards convenient access to the desired area, along with facilities like showers and car parks, and meeting these requirements is the major objective of current installations and maintenance: the reduction in erosion accompanying these activities is a by-product. Conservation measures, if they are maintained, will continue to constrain erosion on the beach dune.

The unfenced, wide pathway of the Coast Walk track at Study Site B traverses gently sloping sandy terrain. Erosional problems are only presented to visitors when rills incise deeply into underlying weathering sandstone or (in sections other than the one studied) into silty clays used in the past to infill major gullies. As the track is unfenced, visitors can create informal pathways whenever the main pathway becomes difficult to traverse. This results 
in increased areas of trampled vegetation and ultimately of bare ground, which will in turn allow for further erosion. Conservation measures on this small section of the 26-km Coast Walk have not been undertaken.

Both study sites display erosion of sandy sediments, but different slope angles and recreational environments are more important than similar soil textures in influencing the nature of current erosional processes and managerial responses.

\section{REFERENCES}

Capararo, G., Mitchell, P., 1995. Fantastic plastic geotextiles stabilise a walking track. Aust. J. Soil Water Conserv. $8,21-25$

Ciccarelli, D., 2014. Mediterranean coastal sand dune vegetation: influence of natural and anthropogenic factors. Environ. Manage. 54, 194-204.

Cole, D.N., 1986. Recreational impacts on backcountry campsites in Grand-Canyon-National-Park, Arizona, USA. Environ. Manage. 10 (5), 651-659.

Cole, D.N., Spildie, D.R., 1998. Hiker, horse, and Ilama trampling effects on native vegetation in Montana, USA. J. Environ. Manage. 53, 61-71.

De Luca, E., Novelli, C., Barbato, F., Menegoni, P., lannetta, M., Nascetti, G., 2011. Coastal dune systems and disturbance factors: monitoring and analysis in central Italy. Environ. Monit. Assess. 183, 437-450.

Department of Agriculture and Department of the Environment, 2012. Maroubra Beach dunes on the mend http://www.nrm.gov.au/funding/approved/pre2008/nsw/sydm/2006-03.html Accessed 24 January 2014

Dragovich, D., Bajpai, S., 2012. Visitor attitudes and erosional impacts on the Coast Walk, Royal National Park. Proc. Linnean Soc. NSW 134, B1 13-B1 18

Gager, P., Conacher, A., 2001. Erosion of access tracks in Kalamunda National Park, Western Australia: causes and management implications. Aust. Geogr. 32, 343-357.

Kutiel, P., Eden, E., Zhevelev, Y., 2000. Effect of experimental trampling and off-road motorcycle traffic on soil and vegetation of stabilized coastal dunes, Israel. Environ. Conserv. 27 (1), 14-23.
Monsef, H.A., Abahussain, A., 2013. The impact of camping activities on soil degradation in Kuwait. J. Environ. Inform. 22 (2), 102-111.

Morgan, R.P.C., Duzant, J.H., 2008. Modified MMF (Morgan-Morgan-Finney) model for evaluating effects of crops and vegetation cover on soil erosion. Earth Surf. Process. Landforms 32, 90-106.

Newsome, D., Milewski, A., Phillips, N., Annear, R., 2002. Effects of horse riding on National Parks and other natural ecosystems in Australia: implications for management. J. Ecotourism 1, 52-74.

Olive, N.D., Marion, J.L., 2009. The influence of userelated, environmental, and managerial factors on soil loss from recreational trails. J. Environ. Manag. 90, 1483-1493.

Phillips, N., Newsome, D., 2002. Understanding the impacts of recreation in Australian protected areas: Quantifying damage caused by horse riding in D'Entrecasteaux National Park, Western Australia. Pacific Conserv. Biol. 7 (4), 256-273.

Randall, M., Newsome, D., 2008. Assessment, evaluation and a comparison of planned and unplanned walk trails in coastal south-western Australia. Conserv. Sci. W. Aust. 7 (1), $19-34$.

Randall, M., Newsome, D., 2009. Changes in the soil micro-topography of two coastal hiking trails in south-western Australia. Conserv. Sci. W. Aust. 7 (2), 279-299.

Randwick City Council, 1996. Maroubra Beach: Plan of Management overview. Prepared for Randwick City Council by Hassell Pty. Ltd. 37p.

Wilson, J.P., Seney, J.P., 1994. Erosional impact of hikers, horses, motorcycles, and off-road bicycles on mountain trails of Montana. Mountain Res. Develop. 14, 77-88.

Wimpey, J., Marion, J.L., 2011. A spatial exploration of informal trail networks within Great Falls Park, VA. J. Environ. Manage. 92, 1012-1022.

Zierholz, C., Hairsine, P., Booker, F., 1995. Run-off and soil erosion in bushland following the Sydney bushfires. Aust. J. Soil Water Conserv. 8, 28-37. 